\title{
Potential Impacts to Wetlands and Water Bodies Due to Mineral Exploration, Pebble Copper-Gold Prospect, Southwest Alaska
}

\author{
Kendra Zamzow ${ }^{1}$ and David M. Chambers ${ }^{2, *}$ (D) \\ 1 Center for Science in Public Participation, Chickaloon, AK 99674, USA \\ 2 Center for Science in Public Participation, Bozeman, MT 59715, USA \\ * Correspondence: dchambers@csp2.org
}

Received: 1 June 2019; Accepted: 17 July 2019; Published: 19 July 2019

check for updates

\begin{abstract}
There is little information in the literature about the impacts of mineral exploration drilling on natural waters. A copper-gold-molybdenum mining deposit in Alaska was heavily explored until 2012 and partially reclaimed; however, full reclamation of drill sites remained incomplete in 2016. Copper is sub-lethally toxic to salmon, a highly-valued resource in this area. Of 109 sites inspected, 9 sites had confirmed impacts due to un-reclaimed drill-holes or drill waste disposal practices. At seven sites artesian waters at the drill stem resulted in surface water or sediment elevated in aluminum, iron, copper, or zinc with neutral $\mathrm{pH}$. Copper concentrations at artesian sites were $<0.4,0.7,2,7,15,76$, and $215 \mu \mathrm{g} / \mathrm{L}$; the latter four exceed water quality criteria. Drilling waste is known to have been disposed of in ponds and unlined sumps. At one of five ponds sampled, copper declined from 51 to $8 \mu \mathrm{g} / \mathrm{L}$ over nine years. At the one sump area with historical data, copper increased from 0.3 to $1.8 \mu \mathrm{g} / \mathrm{L}$ at a downgradient wetland spring over five years. This research identifies contaminant types and sources and can be used to guide future ecotoxicity studies and improve regulatory oversight.
\end{abstract}

Keywords: artesian flow; mining exploration; mine water; reclamation; water quality

\section{Introduction}

Most mining projects do not make it past the exploration stage. This study is a snapshot of the reclamation progress of a major mining exploration site, the Pebble deposit in southwest Alaska. In Alaska mining companies are required to reclaim sites when exploration is suspended, but it can be time-consuming and expensive for regulators to evaluate the progress and success of projects on a regular basis at remote sites. The Pebble site is remote with no roads to or within it.

The site was intensively explored between 2004 and 2012. As mining exploration ceased in 2012 but reclamation activities continued, there was an opportunity to determine the success of reclamation by inspecting the site in 2016. Although the Alaska Department of Natural Resources (DNR) performs annual inspections, they do not include environmental sampling [1,2]. Our goal was to document whether sites appeared fully reclaimed through visual inspection, with a secondary goal to take a limited number of soil and water samples in locations where reclamation did not appear complete to understand potential changes to the environment. This article focuses on observations of water quality at reclamation sites and follows a companion article on soils [3].

\subsection{Exploration of the Ore Deposit}

The Pebble copper-gold-molybdenum ore (Cu-Au-Mo) deposit in southwest Alaska is porphyry-type ore body with sulfide mineralization and few acid-neutralizing carbonate minerals. 
The primary ore mineral is chalcopyrite $\left(\mathrm{CuFeS}_{2}\right)$ with some molybdenite $\left(\mathrm{MoS}_{2}\right)$, and $\mathrm{Au}$ is associated with the principal host rock pyrite $\left(\mathrm{FeS}_{2}\right)[4,5]$. Mineralization reaches the surface in the western zone of the deposit, and angles downward to hundreds of meters below the surface in the eastern zone.

Exploration frequently drilled through more than $1000 \mathrm{~m}$ of bedrock. In the process of exploratory drilling, water pumped from local kettle ponds and creeks was mixed with drilling muds and circulated downhole to keep the drill bit cool and remove drill cuttings to the surface. Drilling waste consists of drill cuttings and drilling muds. Drilling muds generally contain hydrocarbon-based lubricants and sodium bentonite. Waste drilling fluids were discharged directly onto tundra, into ponds, or circulated through unlined drill sump pits to settle cuttings before discharge. In the sumps, heavier materials sank and remaining fluids were disposed of on the tundra. Upon completion, state regulations required drill-holes to be cemented in and overburden placed over sumps for site reclamation.

\subsection{Environmental Risks}

Drilling through sulfide material can pose environmental risks. Mineralized surface rock with sulfides naturally oxidize and undergo abiotic and microbiologic processes that produce sulfuric acid, which in turn dissolves mineral complexes, releasing metals (Equation (1)). This process is called acid mine drainage (AMD).

$$
\mathrm{FeS}_{2}(\mathrm{~s})+7 / 2 \mathrm{O}_{2}+\mathrm{H}_{2} \mathrm{O} \rightarrow \mathrm{Fe}^{2+}+2 \mathrm{SO}_{4}{ }^{2-}+2 \mathrm{H}^{+} .
$$

The development of this world-class ore deposit has been controversial due to concerns that contaminants, particularly $\mathrm{Cu}$, would be released into the environment, in part through dissolution of copper-bearing rock by AMD. Chalcopyrite, molybdenite, and pyrite all produce acid upon oxidation, and chalcopyrite will release $\mathrm{Cu}$ under acidic conditions. Given the mineralization, contaminated soil or water would be expected to have a signature elevated in $\mathrm{Cu}, \mathrm{Mo}, \mathrm{Fe}$, and sulfate. Sodium (Na) from drilling mud residue could also make up part of a signature.

Aquatic life is highly sensitive to divalent metals such as $\mathrm{Cu}$ [6]. Salmonids are particularly sensitive, with $\mathrm{Cu}$ impacts to the gills, olfaction, and lateral line [7-10]. At very low concentrations, $\mathrm{Cu}$ can cause salmonids to lose their ability locate home streams $[10,11]$ or detect alarm pheromones that warn of nearby predators $[7,12]$. Previous work has shown that the natural waters in the Pebble deposit area are very low in $\mathrm{Cu}$, frequently below a detection limit of $0.2 \mu \mathrm{g} / \mathrm{L}$, and low in alkalinity and dissolved organic carbon which could ameliorate $\mathrm{Cu}$ toxicity impacts to some extent $[13,14]$. Research with site water suggests that small increases of $\mathrm{Cu}$ that enter salmonid habitat could quickly become bioavailable [15] with sublethal and acute impacts [7,16].

Although a mine has not been developed, observations by residents and regulators suggested that land and water was being contaminated by drilling waste. Potential contaminant routes could be through drill cuttings disposed of on the surface [3] or in ponds, drill-holes conveying groundwater in contact with sulfides to the surface, or sumps if containment integrity is breached.

\section{Materials and Methods}

\subsection{Site Location}

The site is located $320 \mathrm{~km}$ by air from Anchorage, and $16 \mathrm{~km}$ from Nondalton village. The field sampling crew was based out of Nondalton and transported to the site daily by helicopter. Sampling was conducted from 1-5 August, 2016.

The deposit landscape consists of low rolling hills with lakes, small ponds, wetlands, and over 4000 documented springs [17] and straddles two major watersheds, the Nushagak and the Kvichak (Figure 1). The North Fork Koktuli River and South Fork Koktuli River are along the western and southern boundaries respectively; Upper Talarik Creek runs along the northern and eastern boundaries. All are highly productive salmon streams. Salmon have been documented in tributaries throughout the area, including in waters on top of the ore deposit [18]. 


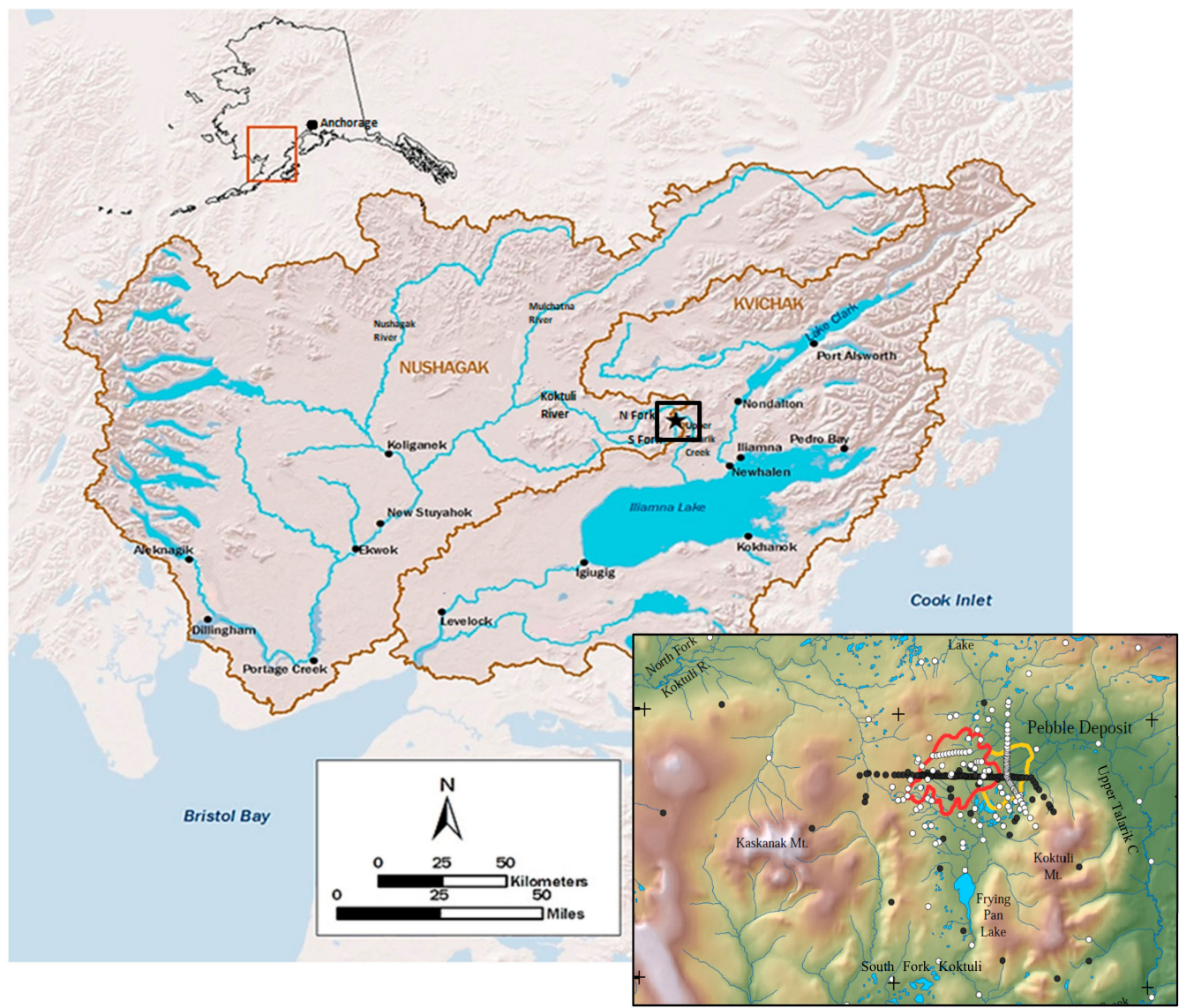

Figure 1. Site location. The location of the mine is shown by the black star $\left(59^{\circ} 54^{\prime} \mathrm{N}, 155^{\circ} 23^{\prime} \mathrm{W}\right)$, north of Iliamna Lake. The mine straddles the Nushagak and Kvichak watersheds which both enter Bristol Bay. Inset: red-western zone of mineral deposit, yellow-eastern zone of deposit, black and white dots-U.S. Geological Survey (USGS) sample sites 2007-2008. Main map adapted from [19]; inset map adapted from [20].

The main deposit is on a plateau at about $305 \mathrm{~m}$ asl, bordered by hills of approximately $450-600 \mathrm{~m}$ asl. At the eastern edge of the deposit lies the "artesian plain," a wide plain abundant with artesian waters that was included in exploratory drilling.

\subsection{Site Selection}

Drill-holes were classified by purpose: DDH (diamond drill-holes) to find ore; GH (geotechnical hole) to determine bedrock integrity and water tables for mine design; $\mathrm{P}$ (piezometer) to monitor the height of the water table; MW monitoring wells for collecting water samples. Drill-hole identifiers start with the year drilled (e.g., DDH 11540 was drilled in 2011; DDH 3129 was drilled in 2003). All GH, P, and MW boreholes $(n=622)$ were less than $200 \mathrm{~m}$ deep while and DDH $(n=733)$ were $12-1958 \mathrm{~m}$ deep. Hypothetically, DDH holes, targeting sulfide mineral zones, would be more likely to have problematic reclamation and water quality issues than $\mathrm{GH}, \mathrm{P}$, or MW drill-holes.

We conducted a desktop review of drill sites, including the locations of the 1355 holes drilled by mining companies and baseline environmental sampling. Baseline soil and water sampling was conducted in the mineral lease area by the Pebble Limited Partnership (PLP) 2004-2008, but not at the drill sites $[13,21]$. U.S. Geological Survey (USGS) conducted soil and water sampling in east-west and north-south transects from 2007-2008 (Figure 1), with some samples co-incident to drill sites [20,22]. Our target sites were chosen based on sites with a documented history of problems, prior sampling by USGS, or observations from the air once on site. 
It was not feasible to visit all sites in the five days of the investigation. In the field, upon landing at a target site if additional drill sites were within walking distance, we opportunistically investigated these. We inspected 19 "clusters" of two to 12 drill-holes (over 70 total drill sites) in this manner. With these additional sites we were able to optimize our time and introduce some randomness into the type of drill site inspected; many of them were documented as fully reclaimed or having no history of problems and would not have been targeted by ourselves or regulators.

\subsection{Field Methods}

Upon arrival at a site, the area was photo-documented, and coordinates were taken from a handheld ETrex 10 GPS. The pH and temperature were measured with a YSI 556 or a YSI 1030 at water bodies adjacent to drill sites, in standing water at the base of drill casings, and from drill-holes with artesian flow. Specific conductance (SC) was measured if there was enough water to immerse the probe. Field meters were calibrated each morning and checked each evening in $\mathrm{pH}$ buffers ( $\mathrm{pH} 4.01$, $7.00,10.01)$ and SC solution $(447 \mu \mathrm{S} / \mathrm{cm})$.

\subsection{Analytical Methods}

Water was collected as grab samples in a 1-liter $(1 \mathrm{~L})$ HDPE container rinsed three times in site water and decanted into laboratory supplied pre-preserved sample bottles. Samples to be analyzed for major elements and total metals were taken to the University of Alaska Applied Science, Engineering, and Technology (ASET) lab in Anchorage, Alaska. Analyses were performed for $\mathrm{pH}$, specific conductance (SC), total organic carbon (TOC), dissolved inorganic carbon (DIC), fluoride (F), chloride $(\mathrm{Cl})$, sulfate $\left(\mathrm{SO}_{4}\right)$, nitrate $\left(\mathrm{NO}_{3}\right)$, beryllium $(\mathrm{Be})$, sodium $(\mathrm{Na})$, magnesium $(\mathrm{Mg})$, aluminum $(\mathrm{Al})$, potassium $(\mathrm{K})$, calcium $(\mathrm{Ca})$, vanadium $(\mathrm{V})$, chromium $(\mathrm{Cr})$, manganese $(\mathrm{Mn})$, iron (Fe), cobalt (Co), nickel (Ni), copper (Cu), zinc (Zn), arsenic (As), selenium (Se), molybdenum (Mo), silver (Ag), cadmium (Cd), antimony (Sb), barium (Ba), thallium (Tl), lead (Pb), thorium (Th), and uranium (U). An ion chromatograph Dionex ICS 5000+ was used to determine anion concentrations. Total metals were determined using an ICP-MS (EPA 200.8, extract method EPA 3050b). No analysis was performed for dissolved metals. Duplicate water samples were collected at three of the 13 sites with water sampling $(23 \%)$. Trip blanks $(n=2)$ and equipment blanks $(n=2)$ were provided to the ASET laboratory. Soil $\mathrm{pH}$ and soil sample analysis was also conducted, and have been described in a separate paper [3].

Three water samples were collected for petroleum analysis, accompanied by sediment or soil samples. Samples were collected in a glass bowl and distributed into amber, $1 \mathrm{~L}$ glass containers provided by the laboratory for residual range organics (RRO) and diesel range organics (DRO) analysis. Samples were submitted to SGS laboratories, Anchorage, Alaska. SGS employed method AK 102/103 with and without silica gel cleanup.

All samples were placed in a cooler containing gel ice, and placed in a refrigerator upon return to the field camp each evening. Samples were transported to the laboratories within two to seven days of collection.

\section{Results}

We inspected 109 sites. Of these, 73 had DDH drill-holes, 32 were GH, MW, or P sites, and four had no markings. Field chemistry on water was collected at 14 sites and on soil at eight additional sites. Soil and vegetation $(n=15)$ was collected at 11 sites and water and sediment samples $(n=19)$ were collected for laboratory analysis at 12 sites (Table 1). A total of 76 sites appeared to be fully reclaimed or had minor issues such as uncapped drill casings and 15 had environmental issues related to soils as described elsewhere and are not further discussed here [3]. The remaining 18 sites had water quality issues or reasons to be concerned about future potential issues. Impacts discussed here are (1) artesian flow at drill-holes, (2) pond water potentially contaminated by drill waste, and (3) sump contents potentially leaching to a wetland. Only the most common analytes observed are discussed, but more complete chemistry is available in Supplementary Information. 
Table 1. Sample set at drill-holes. Only sites with potential water quality concerns based on visual evidence or proximity to water bodies are listed. Bold—sites with impacts to water quality. Two unsampled artesian sites are included in the list of impacted sites based on artesian water chemistry of sampled sites.

\begin{tabular}{lll}
\hline Environmental Concern & Site & Analysis \\
\hline & DDH 7379 & Photos \\
Artesian flow from drill-hole & DDH 7382 & Field; Lab analysis-water, sediment \\
to wetland & DDH 9475 & Field; Lab analysis-water, sediment \\
& GH06-72 & Field; Lab analysis-water \\
& Unidentified & Lab analysis- water \\
\hline \multirow{3}{*}{$\begin{array}{l}\text { Pooled water at or in drill-hole } \\
\text { (potentially artesian) }\end{array}$} & DDH 4202 & Field; Lab analysis-water, sediment \\
& DDH 7381 & Field; Lab analysis-water, sediment \\
& P08-54D & Field \\
\hline Controlled artesian flow & DDH 7365 & Field; Lab analysis-water \\
(standpipe valve) & DDH 7365P & Field; Lab analysis-water \\
\hline \multirow{3}{*}{ Pond adjacent to drill-hole } & GDH 11533P & Field \\
& DDH 12551P & Field; Lab analysis-water, sediment \\
& DDH 3129P & Field; Lab analysis-water, drill cuttings \\
& GH05-60P & Field; Lab analysis-water, drill cuttings \\
\hline Sump contents leaching & DDH 11540 & Field; Lab analysis-water, sediment, sump solids \\
\hline
\end{tabular}

\subsection{Visual Observation}

We visually observed six drill-holes with uncontrolled free-flowing artesian water at the standpipe (Figure 2), one standpipe (DDH 7365) with artesian flow controlled with a valve, and three standpipes surrounded by pooled water that may have been artesian. All but two artesian sites were sampled.

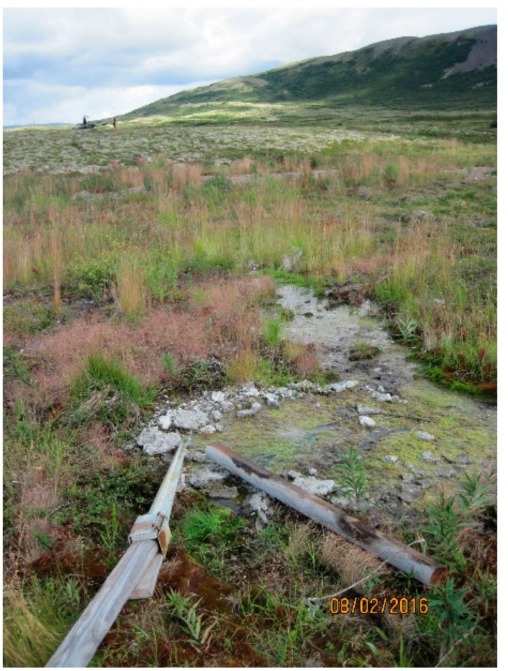

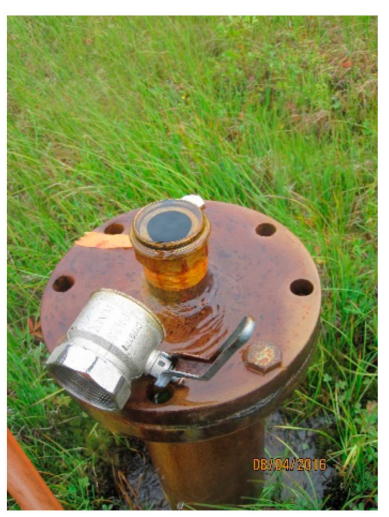

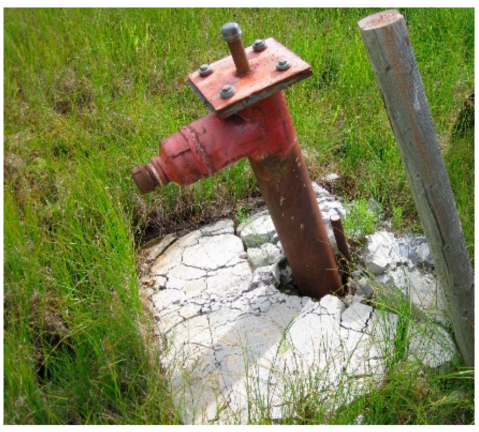

b

Figure 2. Artesian sites. Drilling was conducted in 2007-2008. (a) Artesian flow where drilling occurred at DDH 7386. (b) Artesian flow from a drill stem with a broken valve at DDH 7379. (c) Modified drill stem with no flow observed at DDH 8410. 
DDH 7365 appears to be an operational water source and is discussed further in Section 3.3.2. We also visually observed seven drill sites at which it appeared that modifications-bolts or welded plates were made to the drill stem. All were located on the artesian plain. This suggests the modifications are intended to control artesian flow. However, the ones we observed did not appear to be permanently closed, but rather appeared to have cracking or rusting drill stems that would require repair and maintenance (Figure 2c).

Visual observations of drill cuttings on the surface or dead vegetation were also documented, and field and laboratory samples collected at some of these.

\subsection{Field Chemistry}

Field water chemistry $(n=19)$ was collected at drill-hole standpipes or in adjacent wetlands and ponds. All had neutral $\mathrm{pH} 5.3-7.8$, except wetland water at $\mathrm{pH} 4.9-6.5$, which is within natural range. Surface water temperatures (ponds, wetlands) were $11-24^{\circ} \mathrm{C}$ with specific conductance of $9-109 \mu \mathrm{S} / \mathrm{cm}$. Artesian flow water had lower water temperatures at $6-11^{\circ} \mathrm{C}$ and higher SC of $97-289 \mu \mathrm{S} / \mathrm{cm}$, reflecting groundwater sources. Only one site had field chemistry that indicated a significant issue: artesian water at site DDH 9475 had an SC of $1360 \mu \mathrm{S} / \mathrm{cm}$. The reading was later confirmed by the laboratory.

\subsection{Analytical Chemistry}

At 12 sites, water $(n=13)$ or sediment $(n=6)$ was collected for laboratory analysis to determine whether wetlands or ponds were impacted by drilling. The primary concern was acid mine drainage and the release of $\mathrm{Cu}$. Traditional acid mine drainage was not observed, but areas with elevated $\mathrm{Cu}$ and other metals in water or sediment were observed. Of the sites inspected, six are of particular interest with respect to Cu: artesian sites DDH 4202, DDH 5330, DDH 7382, DDH 7386 and two with contamination related to drilling waste (DDH 11540 and DDH 12551P) (Figure 3).

\subsubsection{Artesian Sites}

We observed free-flowing water issuing from drill-holes at six sites. Artesian water had higher concentrations of select analytes relative to the nearest groundwater seeps (Figure 4), suggesting groundwater was impacted as it was conveyed to the surface via the drill-hole. The most common analytes observed at higher concentrations were $\mathrm{Na}, \mathrm{Al}, \mathrm{Fe}, \mathrm{Cu}, \mathrm{As}$, and $\mathrm{Mo}$. The highest concentrations were observed at DDH 7386 (Al 19,547 $\mu \mathrm{g} / \mathrm{L} ; \mathrm{Fe} 8308 \mu \mathrm{g} / \mathrm{L} ; \mathrm{Cu} 76 \mu \mathrm{g} / \mathrm{L} ; \mathrm{As} 17 \mu \mathrm{g} / \mathrm{L}$ ); all are higher than aquatic life water quality criteria (WQC) although some naturally acidic seeps have even higher concentrations (see Supplementary Materials Tables S1 and S2). This site had water bubbling from the ground in the location where a drill stem had apparently been; water contained gray material that may have been concrete or other material utilized in attempts to close the drill-hole (Figure 2a).

DDH 9475 had elevated sulfate (712 $\mu \mathrm{g} / \mathrm{L}), \mathrm{SC}(1546 \mu \mathrm{S} / \mathrm{cm}), \mathrm{Na}(20 \mathrm{mg} / \mathrm{L}), \mathrm{Al}(289 \mu \mathrm{g} / \mathrm{L})$ and $\mathrm{Mn}$ $(139 \mu \mathrm{g} / \mathrm{L})$. Copper concentration $(2 \mu \mathrm{g} / \mathrm{L})$ was greater than nearby seeps but did not exceeded aquatic life WQC; sediment was not collected. The unidentified site was elevated in $\mathrm{Zn}(66 \mu \mathrm{g} / \mathrm{L})$.

Samples were not collected from artesian water at site DDH 7379. However, the site is worth mentioning in that it was artesian due to a broken valve, while most artesian sites were from uncapped drill stems. We observed another drill stem that had an operational valve in 2016, but which had had free-flowing artesian water in 2008. This is one type of situation in which artesian flow may be intermittent, and determining potential impact may require sampling soil and water.

At three sites (DDH 4202, DDH 5330, P08-54), water was pooled at the base of open drill-stems, but no water was flowing and it was not clear if this was natural wetland water or originated from intermittent artesian flow. Samples were collected at DDH 4202, within a few meters of a beaver pond on the west side of the deposit, and DDH 5330 on the artesian plain.

Like DDH 7386, DDH 4202 contributed Cu greater than aquatic life WQC, although not greater than the nearest seep (Figures 4 and 5). However, $\mathrm{Cu}$ in wetland sediment around DDH 4202 was very high (1892 mg/kg) relative to natural sediment concentrations (median $7 \mathrm{mg} / \mathrm{kg}$, maximum $200 \mathrm{mg} / \mathrm{kg}$ ). 
Sediment at DDH 5330 was elevated in $\mathrm{Fe}, \mathrm{Cu}$, and Mo, with $\mathrm{Cu}$ at $621 \mathrm{mg} / \mathrm{kg}$ (Table 2). This suggests both may have been artesian at one time, with metals sequestering in the sediment, but only DDH 4202 continues to have episodes of artesian flow. Both likely had water in contact with mineralized bedrock. Wetland sediment and water at DDH 5330 were also analyzed for petroleum. Data suggests hydrocarbons were biogenic.

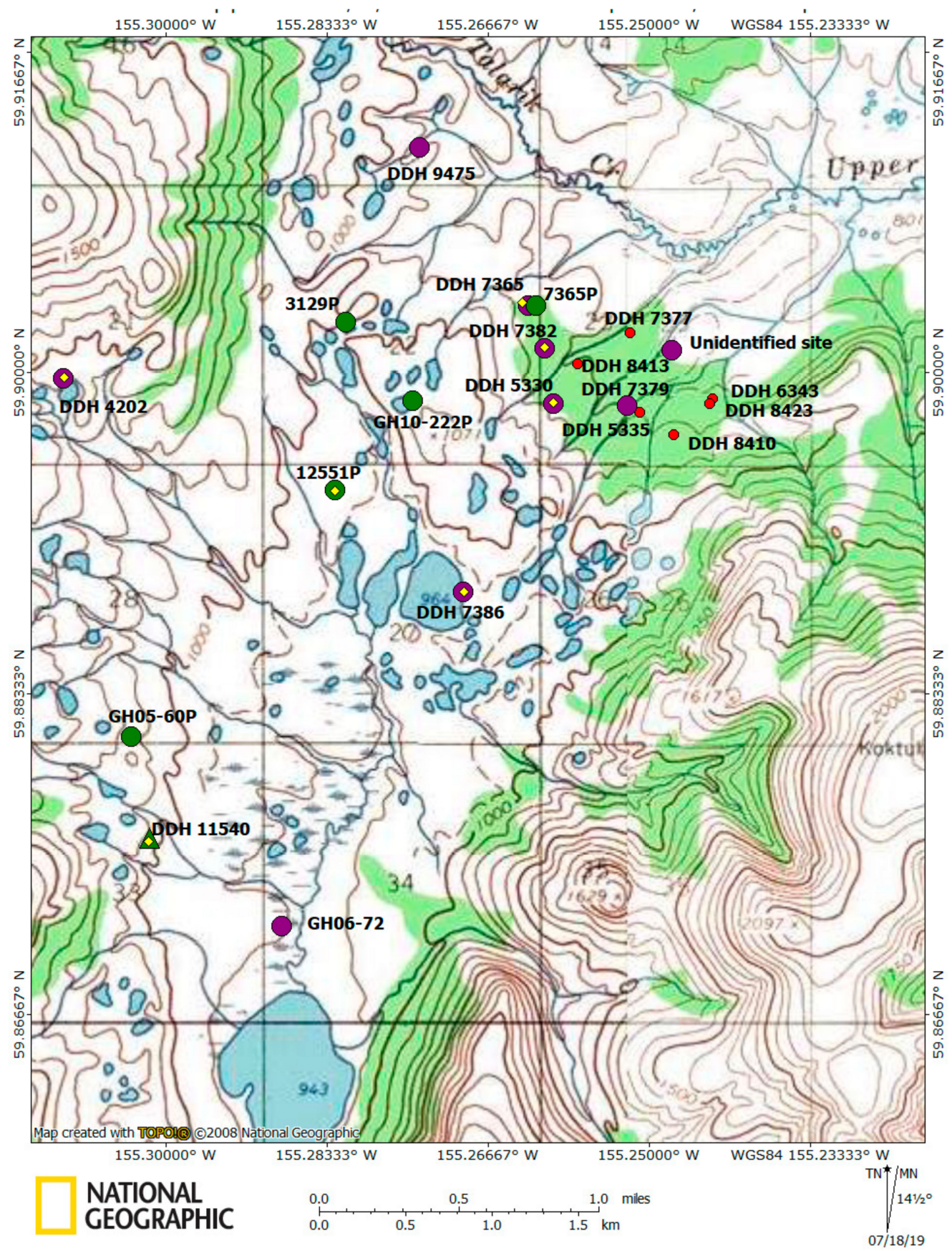

Figure 3. Location of select sites. Sites with laboratory analysis or for which visual inspection suggested current or future environmental issues. Purple circles-openly flowing or potential artesian sites. Red circles-modified drill stems possibly to repress artesian flow. Green triangle-DDH (diamond drill-holes) 11540, where drill sump material appears to be contaminating a wetland spring. Green circles-sites for which laboratory analysis did not show strong evidence of contamination. Locations with elevated $\mathrm{Cu}$ concentrations or trends are noted by a yellow diamond within the circle. Map created using National Geographic TOPO! Software. 


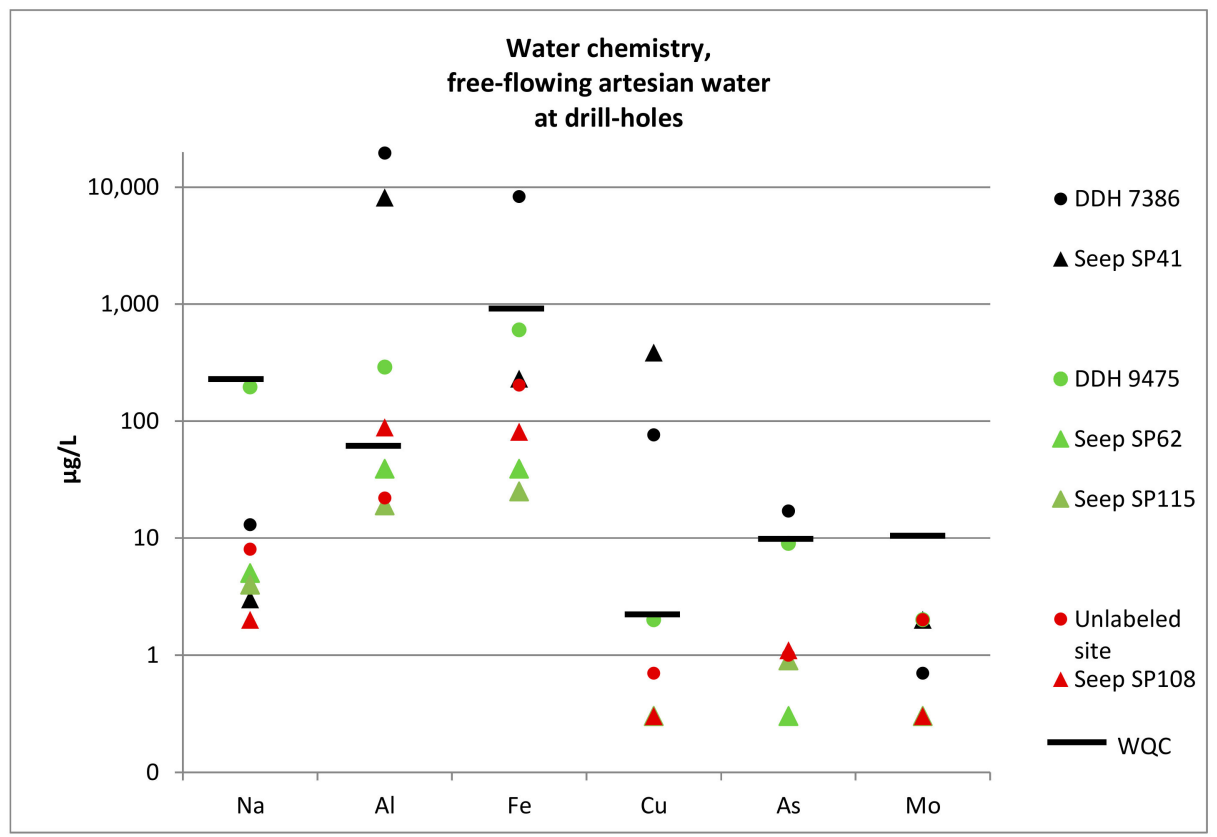

Figure 4. Artesian water chemistry. The most commonly elevated analytes from free-flowing artesian water at three drill-holes, along with maximum concentrations of analytes measured at the geographically closest groundwater seeps. Marker colors associate a drill-hole with the closest seep(s). Black bars-water quality criteria (WQC) for aquatic life [23]. For hardness-dependent metals a hardness of $25 \mathrm{mg} / \mathrm{L}$ was applied. Seep data was collected by Pebble Limited Partnership (PLP) [13].

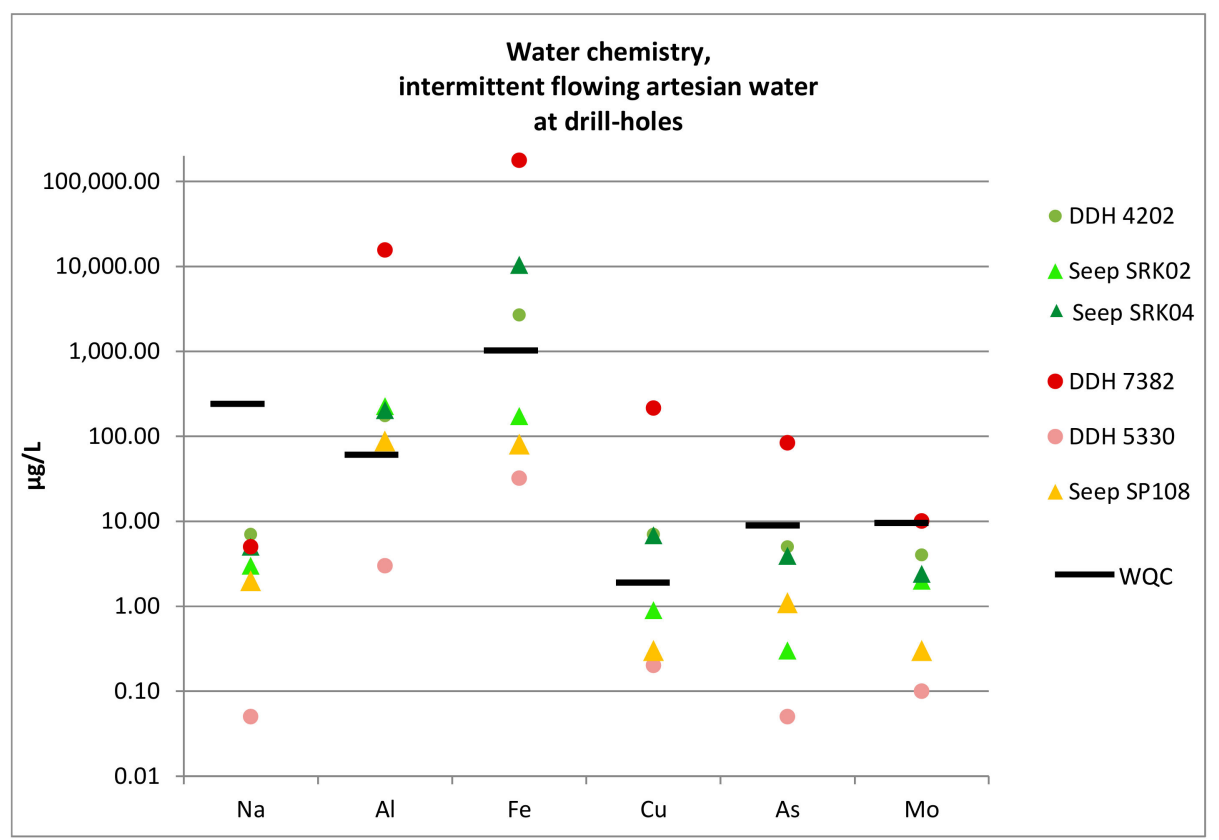

Figure 5. Wetland water chemistry at drill sites. Select chemistry of wetland water surrounding drill-holes with potential artesian flow, and of the nearest seeps. Only commonly elevated analytes are shown. Black bars-WQC for aquatic life [23]. For hardness-dependent metals a hardness of $25 \mathrm{mg} / \mathrm{L}$ was applied. Seep data was collected by PLP [13]. 
Table 2. Sediment chemistry at potentially artesian sites. Both sites had drill stems in a wetland with water pooled at the base. Testing was conducted to determine whether sites had elevated metals indicating artesian flow. "Natural Sediment" $(\mathrm{n}=197)$ concentrations are from PLP [21].

\begin{tabular}{cccccccc}
\hline & $\mathbf{N a}$ & $\mathbf{A l}$ & $\mathbf{F e}$ & $\mathbf{C u}$ & $\mathbf{Z n}$ & As & Mo \\
\hline Site & $\mathbf{m g} / \mathbf{k g}$ & $\mathbf{m g} / \mathbf{k g}$ & $\mathbf{m g} / \mathbf{k g}$ & $\mathbf{m g} / \mathbf{k g}$ & $\mathbf{m g} / \mathbf{k g}$ & $\mathbf{m g} / \mathbf{k g}$ & $\mathbf{m g} / \mathbf{k g}$ \\
\hline Natural sediment, median & 186 & 10,600 & 13 & 7 & 53 & 10 & 1 \\
Natural sediment, max & 630 & 25,200 & 83,400 & 200 & 313 & 270 & 22 \\
\hline DDH 4202 & 72 & 4538 & 19,410 & 1892 & 10 & 26 & 246 \\
DDH 5330 & 199 & 8544 & 16,671 & 621 & 209 & 11 & 78 \\
\hline
\end{tabular}

The highest concentration of $\mathrm{Cu}$ was measured at DDH $7382(\mathrm{Al} 15,609 \mu \mathrm{g} / \mathrm{L} ; \mathrm{Fe} 177,617 \mu \mathrm{g} / \mathrm{L}$; $\mathrm{Cu} 215 \mu \mathrm{g} / \mathrm{L}$; As $84 \mu \mathrm{g} / \mathrm{L}$ ), far exceeding both WQC and maximum concentrations at the nearest groundwater seep. Unlike other artesian sites, the drill stem was capped, not open. A gray material was leaking from a seam in the casing and flowing several meters into a wetland. The base of the drill stem was small-sized gravel, unlike the usual soil at drill-stems, and below that was a material the consistency of putty (Figure 6). Samples were collected from the base of the drill stem and a water-sediment pair was collected in the wetland for general chemistry and petroleum hydrocarbons. Gravel base material had very high $\mathrm{Na}(7707 \mathrm{mg} / \mathrm{kg})$ relative to other sites and natural sediment $(<200 \mathrm{mg} / \mathrm{kg})$, possibly suggesting sodium bentonite. Wetland sediment was elevated in $\mathrm{Fe}, \mathrm{Cu}$, and Mo, with Cu at $186 \mathrm{mg} / \mathrm{kg}$.

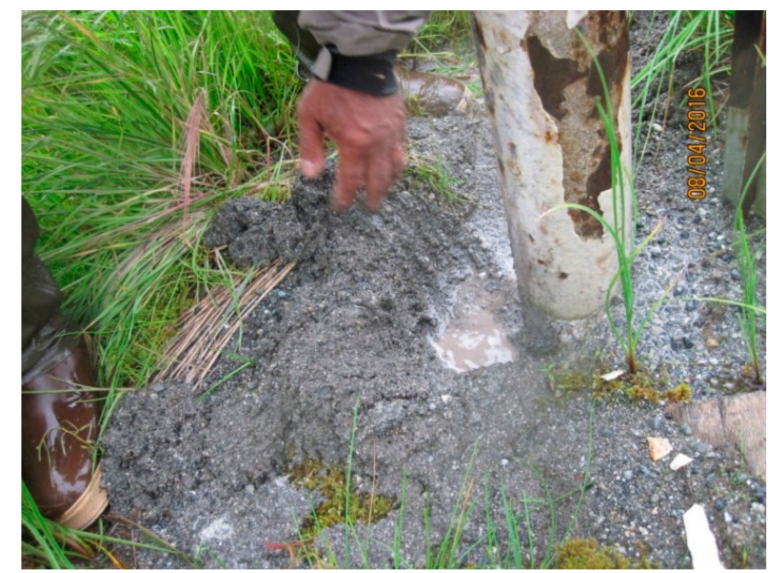

Figure 6. Sample collection at DDH 7382. Material collected at base of drill stem had a gravel texture, but putty-like texture as gravel was scooped away

This was also the only site with strong evidence of petroleum contamination. Diesel Range Organics (DRO) and Residual Range Organics (RRO) were far higher than background (Table 3) and showed a classic chromatogram profile of diesel, while the wetland water and the sample from casing gravel did not show the profile (Figure 7). Casing material potentially did not hold the hydrocarbons as well as organic-rich wetland sediment. 
Table 3. DDH 7382, sediment. A putty-like material at the base of the leaking casing was sampled, along with wetland sediment several meters downgradient. "Natural Sediment" $(n=197)$ is median concentrations from PLP [21], except Diesel Range Organics (DRO) and Residual Range Organics (RRO) are shown as ranges.

\begin{tabular}{lcccccccc}
\hline & $\mathbf{N a}$ & $\mathbf{A l}$ & $\mathbf{F e}$ & $\mathbf{C u}$ & $\mathbf{A s}$ & $\mathbf{M o}$ & DRO & RRO \\
\cline { 2 - 9 } \multicolumn{1}{c}{ Site } & $\mathbf{m g} / \mathbf{k g}$ & $\mathbf{m g} / \mathbf{k g}$ & $\mathbf{m g} / \mathbf{k g}$ & $\mathbf{m g} / \mathbf{k g}$ & $\mathbf{m g} / \mathbf{k g}$ & $\mathbf{m g} / \mathbf{k g}$ & $\mathbf{m g} / \mathbf{k g}$ & $\mathbf{m g} / \mathbf{k g}$ \\
\hline Natural sediment & 186 & 10,600 & 13 & 7 & 10 & 1 & $12-1300$ & $33-12,300$ \\
\hline DDH 7382, soil at base of casing & 7707 & 5492 & 7690 & 12 & 2 & 1 & 42 & 45 \\
DDH 7382, wetland & 72 & 14,261 & 26,517 & 186 & 7 & 37 & 2890 & 6470 \\
\hline
\end{tabular}

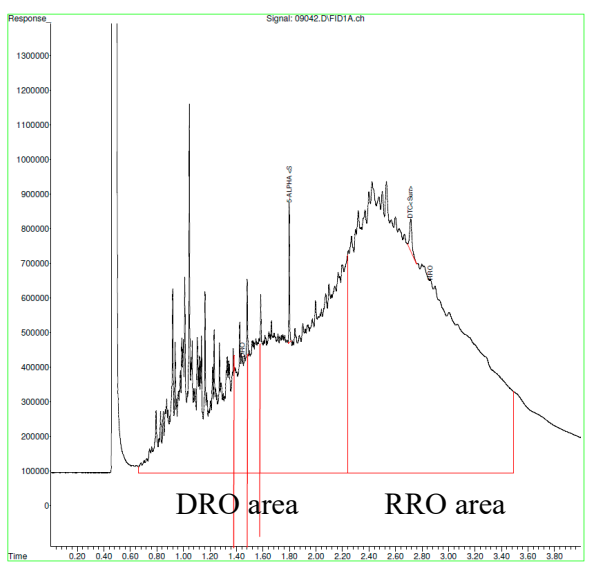

(a)

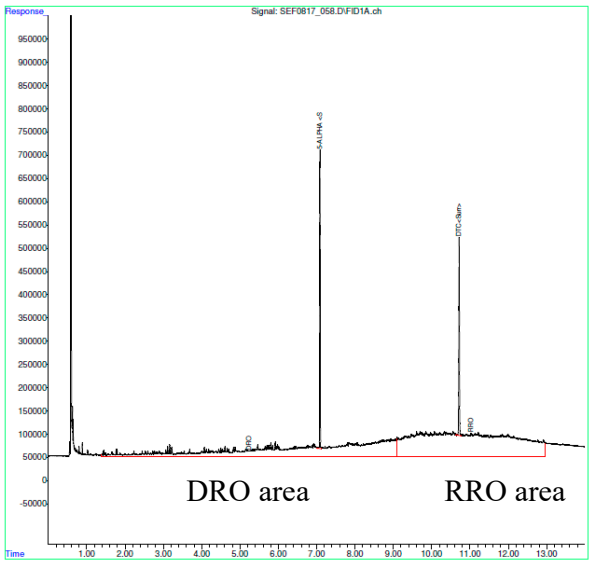

(b)

Figure 7. DDH 7382, petroleum. (a) The wetland sediment sample has the classic "porcupine" profile of diesel ("DRO area"), and the classic "lump" profile for lube oil (which could also represent material from drilling mud) on the left. (b) The chromatogram for wetland water does not show evidence of petroleum. The two large peaks in the pictures are from laboratory tracers. The chromatogram for the sample of material from the base of the casing was similar.

This site was sampled during a rainstorm. The week prior to our inspection, DNR had inspected it and noted no problems nor any recent repairs. Like DDH 4202 and DDH 5330, this is likely a site with intermittent artesian flow affected by groundwater fluctuations, and we may not have observed it under dry weather conditions. DDH 7382 did have a history of problems in the past and a new cap had been installed in September 2015 to control a leak [1].

\subsubsection{Drill Sites Adjacent to Ponds}

Several ponds were sampled by USGS in 2007-2008, providing a historical record for comparison. We collected water-sediment pairs at three ponds: GH05-60P with drill cuttings near the pond, DDH 3129P with drill cuttings and for which USGS noted "drill mud appears to have flowed into pond," and DDH 12551P sampled by USGS and noted to have no evident contamination [20], although at that time DDH 12551 had not been drilled yet.

Pond water with no sediment was collected at two sites. GH10-222P had been previously sampled by USGS, who noted two drill sites (from 2004 to 2005) near the pond at the time. DDH 7365P was a pond downgradient from a capped drill stem with artesian flow under control-a valve could be opened to collect a sample-but which had been a free-flowing artesian drill stem when USGS sampled in 2008 [20].

Of the five ponds we sampled, DDH 12551P was the only one to show strong evidence of contamination (Table 4). More details of pond water and sediment chemistry is in Supplementary Materials Tables S3 and S4. DDH 12551P had elevated Al, Cu, and $\mathrm{Zn}$ in 2007. Pond water $\mathrm{Cu}$ declined from $51 \mu \mathrm{g} / \mathrm{L}$ in 2007 to $8 \mu \mathrm{g} / \mathrm{L}$ in 2016 but remained above WQC. Pond sediment had higher 
$\mathrm{Cu}$ concentrations $(78 \mathrm{mg} / \mathrm{kg})$ than the median for natural sediment $(7 \mathrm{mg} / \mathrm{kg})$ but was within the range observed throughout the mine area $(200 \mathrm{mg} / \mathrm{kg})$; Fe was similarly well above median sediment concentrations $(5723 \mathrm{mg} / \mathrm{kg}$ vs. median $13 \mathrm{mg} / \mathrm{kg}$ ) but within the range (maximum 83,400 mg/kg). There was widespread dead vegetation in the area suggesting possible near-surface drill waste disposal.

Table 4. Pond chemistry. Pond samples are labeled using the drill-hole closest to the pond and the letter " $\mathrm{P}$ " to distinguish the pond sample from samples at the drill-stem. Bold-concentration exceeds WQC. WQC - water quality criteria for aquatic life [23]; for hardness-dependent metals a hardness of $25 \mathrm{mg} / \mathrm{L}$ was applied. Lake data is from [13]. LOD = limit of detection

\begin{tabular}{|c|c|c|c|c|c|c|c|c|}
\hline & $\mathrm{pH}$ & $\mathrm{Na}$ & Al & $\mathrm{Fe}$ & $\mathrm{Cu}$ & $\mathrm{Zn}$ & As & Mo \\
\hline Site & & $\mathrm{mg} / \mathrm{L}$ & $\mu \mathrm{g} / \mathrm{L}$ & $\mu \mathrm{g} / \mathrm{L}$ & $\mu \mathrm{g} / \mathrm{L}$ & $\mu \mathrm{g} / \mathrm{L}$ & $\mu \mathrm{g} / \mathrm{L}$ & $\mu \mathrm{g} / \mathrm{L}$ \\
\hline Aquatic life WQC & $6.5-8.5$ & na & 87 & 1000 & 2.9 & 37 & 150 & na \\
\hline Lakes, range (median) & $4.7-8.6(7.4)$ & $0.4-13(2)$ & $5-380(32)$ & $18-2150(180)$ & $0.2-4(0.4)$ & $0.7-15(2)$ & $0.3-7(0.3)$ & $0.02-2(0.2)$ \\
\hline DDH 12551P, 2007 & 5.8 & 4 & 149 & $<50$ & 51 & 63 & $<\mathrm{LOD}$ & $<2$ \\
\hline DDH 12551P, 2008 & 5.6 & 4 & na & 29 & 17 & 16 & 0.1 & 0.05 \\
\hline DDH 12551P, $2016^{\text {a }}$ & 6.7 & 2 & 100 & $<63$ & 8 & 4 & 0.3 & $<0.2$ \\
\hline
\end{tabular}

At site DDH 7365, water in the standpipe itself has increased in Fe $(369 \mu \mathrm{g} / \mathrm{L}-2265 \mu \mathrm{g} / \mathrm{L})$ and $\mathrm{Cu}$ $(3 \mu \mathrm{g} / \mathrm{L}$ to $15 \mu \mathrm{g} / \mathrm{L}$ ) over time, but the pond did not appear to be affected. At GH05-60P, Al and Fe were elevated but trace metals were not, suggesting that the proximity of drill cuttings was not affecting pond water quality; however, this pond had no historical data so no trends could be observed. Ponds 3129P and GH10-222P did not have unusual water chemistry. Sediment was not sampled in these.

\subsubsection{Waste Sump Leaching}

At DDH 11540 (Figure 8), drill waste fluid samples were collected in 2011 from a sump during drilling and from a small, clear, groundwater spring downgradient [24]. There was visual observation of drill fluid flowing into the wetland in 2011, however laboratory testing indicated the spring was not affected at that time. In 2016, sump material was retrieved from inside the covered drill sump for analysis and samples of water and sediment were collected at the groundwater spring.

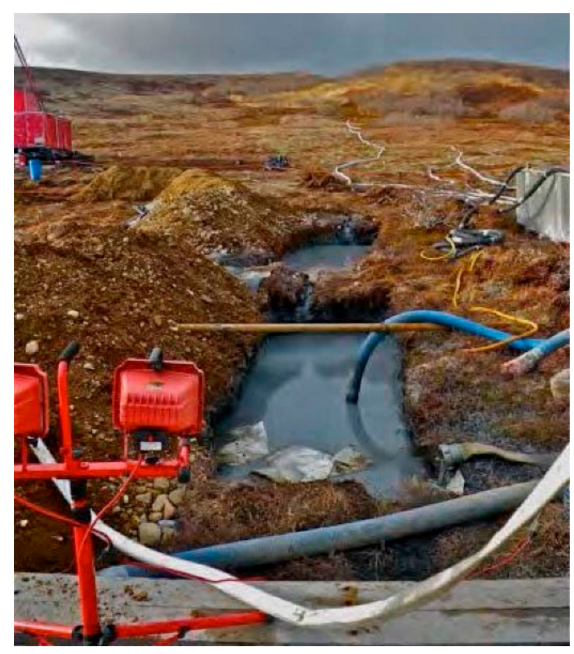

a

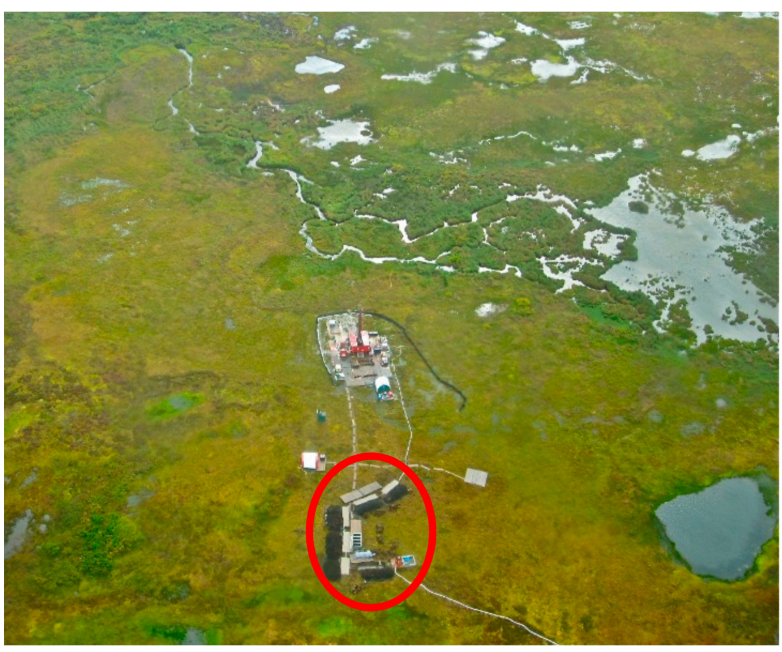

b

Figure 8. Drill waste sumps. (a) Drill waste sumps. (b) Drilling at site 11540 in 2011 . Red circle indicates location of drill waste sumps. Photo credit: M. Welker, R. Halford.

The wetland groundwater spring in 2016 had the same $\mathrm{pH}$ and SC as the 2011 sample, but $\mathrm{Al}, \mathrm{Mn}$, $\mathrm{Fe}, \mathrm{Cu}, \mathrm{Zn}$, and Mo were higher in 2016 (Figure 9, Supplementary Materials Table S5). This suggests metals contained in the waste sump may be mobilizing into the surrounding wetland and groundwater. 
$\mathrm{Al}$ and Fe increased in concentration and now exceed WQC; if the trend continues, Cu could exceed in time.

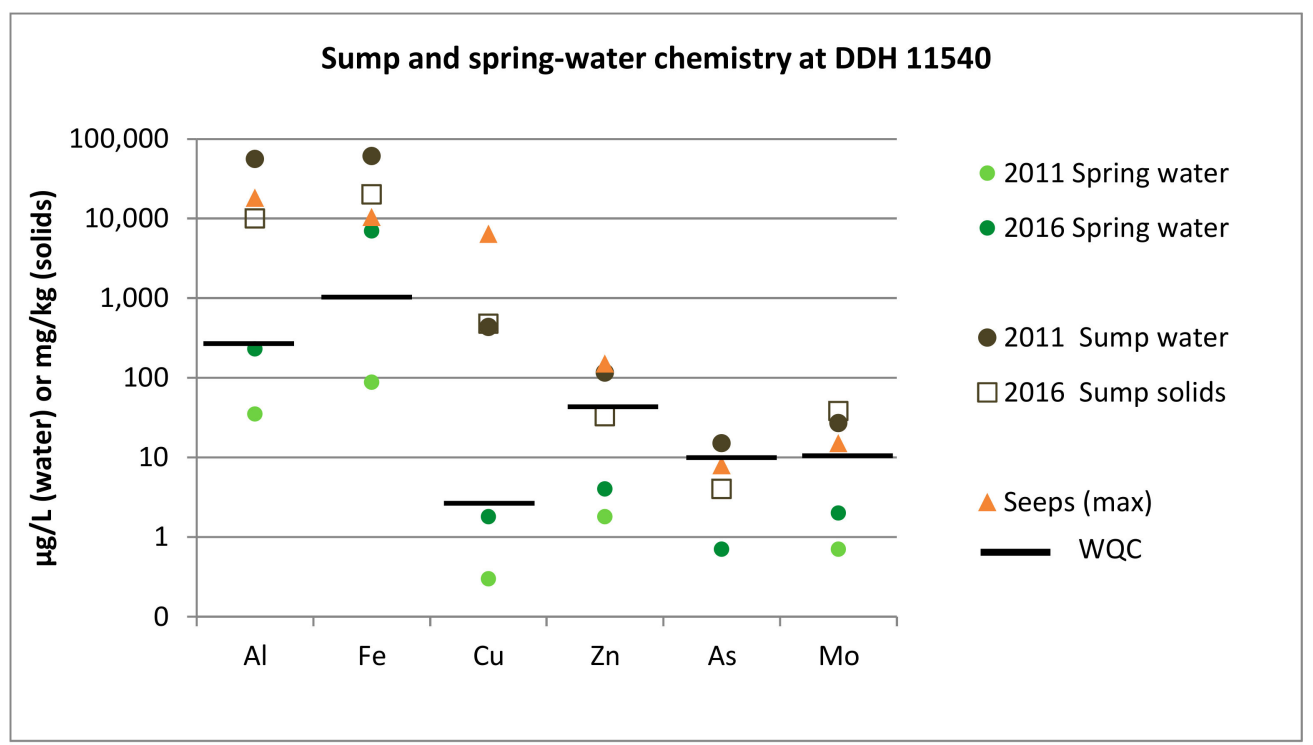

Figure 9. Wetland spring at drill waste sump. Drill waste sump contents were sampled in 2011 (water) and 2016 (solids), as was a wetland spring downgradient. Concentrations for water are in $\mu \mathrm{g} / \mathrm{L}$ and for solids are in $\mathrm{mg} / \mathrm{kg}$, both on the left vertical axis. Black bars-WQC for aquatic life [23]. For hardness-dependent metals a hardness of $25 \mathrm{mg} / \mathrm{L}$ was applied. Seep data was collected by PLP [13].

\section{Discussion}

Mining is expected to continue to expand in Alaska. As most exploration will not progress to full scale mines, it is important to understand how exploration itself may have impacts. This project was undertaken to view the success of reclamation and whether there were contaminant issues related to exploration drilling that could impact salmon. We inspected 109 of the 1355 drill-holes documented and generally targeted sites that had problems in the past. As expected, most issues were associated with DDH (exploration) drill-holes, rather than geotechnical or other types of drilling. As we targeted problem sites, and because about half the 1355 holes were not exploratory, results should not be extrapolated.

There is evidence that acid drainage is occurring at the micro scale on exposed drill cuttings [3], but it is not evident at the macro scale. However, environmental contamination was occurring. Copper was entering wetlands by way of artesian flow, and it appears that permanently closing artesian sites has been a chronic problem. Drill holes should be permanently sealed or fitted with operational valves for water collection; this is not only good practice, but a legal requirement in Alaska [25]. Where it has been difficult to control artesian flow, environmental sampling during annual state inspections could be conducted to determine the extent of impact.

The practice of disposing of drilling waste hundreds of feet from the drill-hole made it impractical to attempt to systematically determine potential impacts; disposal locations were not documented.

\subsection{Artesian Sites}

Artesian water pressure was the most common environmental issue observed that prevented permanent closure of drill-holes and final reclamation. Artesian flow contributed elevated concentrations of metals, frequently $\mathrm{Cu}$, to surrounding wetlands.

Artesian flow was present at sites drilled as early as 2004 (DDH 4202) and as recently as 2009 (DDH 9475), and modified drill-stems were present at sites drilled between 2005 and 2008. Their presence indicates chronic problems with closure at some sites, not isolated to one geographic area. Repair work such as cementing, bentonite pellets, and Margo plug replacement should be reported to DNR to 
provide regulators with a historical track record as well as notification of sites that deserve annual inspection. This could be useful in understanding impacts at other mineral exploration sites.

\subsection{Sites with Drilling Waste}

Drilling waste disposal may be impacting two sites. At pond DDH 12551P no artesian drill-holes were observed, and USGS did not notice any contamination in 2008, but areas of dead vegetation suggest that drilling waste could be the source of elevated $\mathrm{Cu}$ concentrations in the pond. This may have occurred after USGS sampling. No obvious drill waste sumps were observed. We observed four drilling sites around the pond (DDH 4171, DDH 11535, DDH 12551, P04-04M), and the pond may have been used for disposing of drill waste. This is a relatively common practice allowed under state law. Disposal of drill waste may take place several hundred feet from the actual drill holes; these locations are not documented a practice which makes it difficult to determine whether waste disposal has impacted landscapes or water bodies.

Ponds in the area are fed with groundwater or only with meteoric water; those fed only with meteoric water tend to dry up in the summer, leaving wide exposed banks clear of vegetation, and will be less able to flush contaminants [26]. DDH 12551P was such a pond. The only other meteoric pond sampled, DDH 3129P, did not have elevated $\mathrm{Cu}$ in pond water $(2 \mu \mathrm{g} / \mathrm{L})$ despite the presence of drill cuttings with high $\mathrm{Cu}(1036 \mathrm{mg} / \mathrm{kg}$, data not shown) on the banks; pond sediment was not collected. The extent to which ponds are accessed by salmon has not been studied, although it is known that salmon travel through gravel of the hyporheic zone and reach locations that appear isolated from rivers [18].

At site DDH 11540, drill waste was run through a series of five sumps prior to disposal on the land. It appears likely that the sumps are leaching metals into a groundwater spring and may exceed $\mathrm{Cu}$ WQC in the near future if trends continue. Further work should be done to determine whether it continues to leach, what contributes to the leaching (e.g., rain or high water table, proximity of wetland), and whether other drill waste sumps may have similar issues. This may be part of a wider problem at drill waste pits that has not been identified due to lack of data.

\section{Conclusions}

Sites with contamination were not extensive, but some risks could be long-term. Copper has sequestered in wetland and pond sediment. Copper concentration was highest in water at artesian sites DDH $7386(76 \mu \mathrm{g} / \mathrm{L})$ and DDH $7382(215 \mu \mathrm{g} / \mathrm{L})$, and at pond 12551P (declining from 51 to $8 \mu \mathrm{g} / \mathrm{L}$ over nine years) which may have acted as a repository for drilling waste; these concentrations are over the WQC of $2.9 \mu \mathrm{g} / \mathrm{L}$ and well over natural background, which was frequently below $0.5 \mu \mathrm{g} / \mathrm{L}$.

The results of this investigation provide direction on the sources and types of contamination. Future research should sample pond sediment, where contaminants from drill waste may sequester, and investigate drill waste sumps for evidence of leaching. It would be in the public interest for state regulators to conduct water, soil, or sediment sampling during inspections to monitor environmental changes where drill holes are not fully and permanently reclaimed. In addition to documenting impacts at sites where artesian pressure makes drill-hole closure difficult, such sampling would assist regulators with determining whether they should restrict the disposal option for drill cuttings from rock containing metal sulfides.

Supplementary Materials: The following are available online at http://www.mdpi.com/2076-3298/6/7/84/s1, Table S1: Acid seep water quality; Table S2: Artesian sites; Table S3: Sump contents at wetland spring and sediment at pond 12551P; Table S4: Pond water chemistry; Table S5: Wetland spring water downgradient from drill waste sump.

Author Contributions: Conceptualization, K.Z.; Data curation, K.Z.; Formal analysis, K.Z.; Funding acquisition, D.M.C.; Investigation, K.Z. and D.M.C.; Methodology, K.Z.; Writing—original draft, K.Z.; Writing—review \& editing, K.Z. and D.M.C. 
Funding: This research was funded by United Tribes of Bristol Bay (no grant number). We were able to prepare this paper through funding from the Edgerton Foundation (no grant number).

Acknowledgments: The authors would like to acknowledge George Alexie for assistance in the field.

Conflicts of Interest: The authors have no financial interests that could bias or influence the work. However, funding for field work was supplied by the United Tribes of Bristol Bay (utbb.org), a group known to actively oppose development of the Pebble Project. The authors may have personal interests that could be considered a bias. The authors have been called as expert witnesses in a case against the state of Alaska related to the Pebble Project, in 2009. The authors have assisted NGOs, including United Tribes of Bristol Bay, by providing technical review of material related to Pebble project permitting, such as review of baseline information gathered by the Pebble Limited Partnership. The authors held no bias in conducting the work related to this paper. They approached and reported on the project objectively. The funders had no role in the design of the study; in the collection, analyses, or interpretation of data; in the writing of the manuscript, or in the decision to publish the results.

\section{References}

1. Cole, W. Field Inspection of the Pebble Copper/Gold Project. 26-27 July 2007. Alaska Department of Natural Resources (ADNR): Anchorage, AK, USA, 2007. Available online: http://www.dnr.state.ak.us/mlw/mining/l argemine/pebble/field-reports/index.cfm (accessed on 14 October 2016).

2. Alaska Department of Natural Resources (ADNR). Inspection and Field Reports. Available online: http: //www.dnr.state.ak.us/mlw/mining/largemine/pebble/field-reports/index.cfm (accessed on 16 January 2019).

3. Chambers, D.M.; Zamzow, K.Z. Documentation of acidic mining exploration drill cuttings at the Pebble copper-gold mineral prospect, Southwest Alaska. Environments 2019, 6, 78. [CrossRef]

4. Pebble Limited Partnership (PLP). Pebble Project Environmental Baseline Document 2004 through 2008; Chapter 3 Geology and Mineralization, Bristol Bay Drainages; Pebble Limited Partnership (PLP): Anchorage, AK, USA, 2011.

5. Pebble Limited Partnership (PLP). Pebble Project Supplemental Environmental Baseline Document 2004 through 2012; Chapter 11 Geochemical characterization, Section 11.7, Table 11-22; Pebble Limited Partnership (PLP): Anchorage, AK, USA, 2018.

6. Meyer, J.S.; Clearwater, S.J.; Doser, T.A.; Rogaczewski, M.J.; Hansen, J.A. (Eds.) Effects of Water Chemistry on Bioavailability of Toxicity of Waterborne Cadmium, Copper, Nickel, Lead and Zinc to Freshwater Organisms; Society of Environmental Toxicology and Chemistry(SETAC) Press: Pensacola, FL, USA, 2007.

7. Morris, J.M.; Brinkman, S.F.; Takeshita, R.; McFadden, A.K.; Carney, M.W.; Lipton, J. Copper toxicity in Bristol Bay headwaters: Part 2-olfactory inhibition in low-hardness waters. Environ. Toxicol. Chem. 2019, 1, 198-209. [CrossRef] [PubMed]

8. Hecht, S.A.; Baldwin, D.H.; Mebane, C.A.; Hawkes, T.; Gross, S.J.; Scholz, N.L. An Overview of Sensory Effects of Juvenile Salmonids Exposed to Dissolved Copper: Applying a Benchmark Concentration Approach to Evaluate Sublethal Neurobehavioral Toxicity. NOAA; October 2007. Technical memorandum NMFS-NWFSC-83. Available online: https://www.nwfsc.noaa.gov/assets/25/606_11162007_114444_Sensory EffectsTM83Final.pdf (accessed on 5 January 2019).

9. McIntyre, J.K.; Baldwin, D.H.; Meador, J.P.; Scholz, N.L. Chemosensory deprivation in juvenile coho salmon exposed to dissolved copper under varying water chemistry conditions. Environ. Sci. Technol. 2008, 42, 1352-1358. [CrossRef] [PubMed]

10. Baldwin, D.H.; Tatara, C.P.; Scholz, N.L. Copper-induced olfactory toxicity in salmon and steelhead: extrapolation across species and rearing environments. Aquat. Toxicol. 2011, 101, 295-297. [CrossRef] [PubMed]

11. Kennedy, C.J.; Stecko, P.; Truelson, B.; Petkovich, D. Dissolved organic carbon modulations the effects of copper on olfactory-mediated behaviors of Chinook salmon. Environ. Toxicol. Chem. 2012, 31, 2281-2288. [CrossRef] [PubMed]

12. McIntyre, J.K.; Baldwin, D.H.; Beuchamp, D.A.; Scholz, N.L. Low-level copper exposures increase visibility and vulnerability of juvenile coho salmon to cutthroat trout predators. Ecol. Appl. 2012, 22, 1460-1471. [CrossRef] [PubMed]

13. Pebble Limited Partnership (PLP). Pebble Project Environmental Baseline Document 2004 through 2008; Chapter 9 Water Quality; Pebble Limited Partnership (PLP): Anchorage, AK, USA, 2011. 
14. Zamzow, K. Investigation of Surface Water Quality in the Nushagak, Kvichak, and Chulitna Watersheds, Southwest Alaska, 2009-2010; Center for Science in Public Participation, Bozeman, MT; The Nature Conservancy: Anchorage, AK, USA, 2011.

15. Craven, A.M. The Importance of Dissolved Organic Matter to the Binding of Copper and the Release of Trace Elements from Coal Ash. Chemistry and Biochemistry Graduate Theses and Dissertations Paper 76. Ph.D. Thesis, University of Colorado, Boulder, CO, USA, 2012.

16. Morris, J.M.; Brinkman, S.F.; Carney, M.W.; Lipton, J. Copper toxicity in Bristol Bay headwaters: Part 1-Acute mortality and ambient water quality criteria in low-hardness water. Environ. Toxicol. Chem. 2019, 1, 190-197. [CrossRef] [PubMed]

17. Pebble Limited Partnership (PLP). Pre-permitting Environmental/Socio-economic Data Report Series; Report D-6: Seep Inventory Site Plan; Pebble Limited Partnership (PLP): Anchorage, AK, USA, 2008.

18. Woody, C.A.; O'Neal, S.L. Fish Surveys in Headwater Streams of the Nushagak and Kvichak River Drainages, Bristol Bay, Alaska, 2008 and 2009; The Nature Conservancy: Anchorage, AK, USA, 2009.

19. U.S. Environmental Protection Agency. An Assessment of Potential Mining Impacts on Salmon Ecosystems of Bristol Bay, Alaska. Region 10; EPA 910-R-14-001; US Environmental Protection Agency: Seattle, WA, USA, 2014. Available online: https://www.epa.gov/sites/production/files/2015-05/documents/bristol_bay_assessm ent_final_2014_es.pdf (accessed on 7 January 2019).

20. Fey, D.L.; Granitto, M.; Giles, S.A.; Smith, S.M.; Eppinger, R.G.; Kelley, K.D. Geochemical Data for Samples Collected in 2008 Near the Concealed Pebble Porphyry Cu-Au-Mo Deposit, Southwest Alaska; Open-File report 2009-1239; US Geological Survey: Reston, VA, USA, 2009.

21. Pebble Limited Partnership (PLP). Pebble Project Environmental Baseline Document 2004 through 2008; Chapter 10 Trace Elements; Pebble Limited Partnership (PLP): Anchorage, AK, USA, 2011.

22. Fey, D.L.; Granitto, M.; Giles, S.A.; Smith, S.M.; Eppinger, R.G.; Kelley, K.D. Geochemical Data for Samples Collected in 2007 Near the Concealed Pebble Porphyry Cu-Au-Mo Deposit, Southwest Alaska; Open-File report 2008-1132; US Geological Survey: Reston, VA, USA, 2008.

23. Alaska Department of Environmental Conservation (DEC). Alaska Water Quality Criteria Manual for Toxic and Other Deleterious Organic and Inorganic Substances; Alaska Department of Environmental Conservation (DEC): Anchorage, AK, USA, 2008.

24. Woody, C.A.; Zamzow, K.; Welker, M. Water quality at Pebble prospect drill rig \#6, South Fork Koktuli River, Bristol Bay, Alaska, 22-23 Oct. 2011. United Tribes of Bristol Bay: Dillingham, AK, USA, 2012. Available online: http://pebblescience.org/pdfs/2013-July/SUMP_Final_9_July_2012compressed.pdf (accessed on 7 January 2019).

25. Alaska Department of Natural Resources (ADNR). Multiple Land Use Permit 2014-2016 MLUP \#6118. Available online: http://dnr.alaska.gov/mlw/mining/largemine/pebble/pdf/a156118permit.pdf (accessed on 7 January 2019).

26. Rains, M.C. Water sources and hydrodynamics of closed-basin depressions, Cook Inlet region, Alaska. Wetlands 2019, 31, 377-387. [CrossRef]

(C) 2019 by the authors. Licensee MDPI, Basel, Switzerland. This article is an open access article distributed under the terms and conditions of the Creative Commons Attribution (CC BY) license (http://creativecommons.org/licenses/by/4.0/). 